\title{
THE IMPACT OF CREDIT RISK ASSESSMENT ON CREDIT ACTIVITY OF COMMERCIAL BANKS ${ }^{* * *}$
}

As banks have great social responsibility and are a subject to a specific and extensive regulations, one of the being Basel, the authors of this paper focus on the impact of credit risk assessment on credit activity of commercial banks. The authors of this paper provide a standard for risk management and an insight into directions on how to manage credit risk in the most efficient way and how to assess credit rating of a borrower.

Key words: Basel II and III, credit risk, credit activity of commercial banks, risk management

\section{Introduction}

As banks have great social responsibility and are a subject to a specific and extensive regulations, one of the being Basel, the authors of this paper focus on the impact of credit risk assessment on credit activity of commercial banks. Since 2009, after initial credit expansion, negative macroeconomic tendencies, economic slowdown and decrease in standard of living have led to reduction in the quality of bank credit portfolio while the drop in credit activity sped up the process of this deterioration. ${ }^{1}$ This phenomenon has contributed to the interest in assessing credit risk that has been considerable in recent years.

Associate Professor Marijana Ljubić, PhD, Faculty of Business Studies, John Naisbitt University (Megatrend University), Belgrade, e-mail: mljubic@megatrend.edu.rs

** Professor Vladan Pavlović PhD, University of Priština, temporarily seated in Kosovska Mitrovica Faculty of Economics, e-mail: vladan.pavlovic@pr.ac.rs

*** Professor Srećko Milačić PhD, University of Pristina, temporarily seated in Kosovska Mitrovica Faculty of Economics, e-mail:_srecko.milacic@pr.ac.rs

**** This paper is a part of the results within research on project 179001, financed by Ministry of education, science and technological development of the Republic of Serbia.

$1 \quad$ Ljubić. Marijana (2011): "Stress tests as an instrument of risk control in banks", Megatrend Review, 1/2011, 303-324 


\section{Risk management in banking}

A bank identifies measures and assesses the risks it is exposed to with the aim to manage them. It is liable to form a specific organizational unit responsible for managing risks. Risk management is in accordance with the size and organizational structure of a bank and the volume and type of its activities. Pursuant to the Decision on risk management, a bank shall establish such internal organization/ organizational structure by which the activities of risk management (middle office) and support activities (back office) would be functionally and organizationally separated from risk assumption (front office), with a clearly defined division of employees' tasks and duties that prevents conflict of interest (front office). A bank shall establish an effective and efficient risk management process which encompasses mitigation, monitoring and control of risks that the bank is or may be exposed to and which it identified and measured and/or assessed.

Law on Banks of the Republic of Serbia classifies the risks a bank is exposed to in the following way: 1) liquidity risk; 2) credit risk; 3) interest rate risk, foreign exchange risk and other market risks; 4) risk of exposure of bank to one person or a group of related persons; 5) investment risks in other legal persons, fixed assets and bank investment real estate; 6 ) risks relating to the country of origin of the entity to which a bank is exposed; 7) operational risk, which particularly includes legal risk and inappropriate management of information and other technologies important for business operations. ${ }^{2}$

The Decision on risk management has classified the risks bank may be exposed in a slightly more detailed way. The Decision states that banks are particularly exposed to or may be exposed to the following risks: 1) liquidity risk; 2) credit risk, including residual risk, dilution risk, settlement/delivery risk and counterparty risk; 3) interest rate risk; 4) foreign exchange risk and other market risks; 5) concentration risk, which particularly includes risks of exposure of the bank to one person or a group of related persons; 6) investment risks; 7) risks relating to the country of origin of the entity to which a bank is exposed (country risk); 8) operational risk, which particularly includes legal risk; 9) risk of compliance of the bank's operations; 10) strategic risk, 11) other risks. ${ }^{3}$

Credit risk is a basic bank risk and it represents the most significant risk that a bank is exposed to in its operations. It is as old as banking is, and each process of lending money to a counterparty involves a danger that assets might not be paid off in due time and in accordance with the agreed

Zakon o bankama, Službeni glasnik Republike Srbije, 107/2005, 91/210, 14/2015

Odluka o upravljanju rizicima banke, Službeni glasnik Republike Srbije, 45/2011, 94/2011, $119 / 2012,123 / 2012,23 / 2013,43 / 2013,92 / 2013$ 
terms. ${ }^{4}$ This requires a system of credit risk management which provides accurate and duly credit risk rating and precise classification of credits among priorities that should be supervised the most. Risk management involves several phases: (1) risk identification, (2) risk analysis, (3) risk measurement, (4) risk monitoring, and (5) risk control..$^{5}$ Identification and assessment of credit risk is actually the first step in the process of acting on it effectively.

The Central Bank expects national banks to have a credit risk management system which provides an accurate and duly risk rating. Also, Central Bank considers accurate credit classification one of its priorities which should be supervised in detail. According to Basel standards, depending on the amount of bank's capital, it is important to recruit a certain number of experts who will be dealing exclusively with the process of monitoring credit risk as the key risk in banking operations.

\subsection{Procedures for assessment of credit risk acceptability in banks}

Within the standards and procedures used for measuring and controlling risks in banking operations, there are specific procedures concerned with credit risk. The authors of this paper provide a standard for risk management and an insight into directions on how to manage credit risk in the most efficient way and how to assess credit rating of a borrower.

The procedures for assessment of acceptability of credit risk have a key role in his process. They primarily inform Board of directors and management about weaknesses of borrower's credit rating assessment, often supporting administration activities and expenses that this process requires. They describe specific loans whose payoff is questionable and which, if it was not paid off, would have a significant effect on the bank's concept of capital increase. These are recommended for particularly important and classified national loans, e.g. when management does not agree with the classification, when (insider) loan has unfavourable assessment or when the breach of law is involved. It is presented in a written form, and contains comments relevant to loans and potential debts which are subject to unfavourable price. Ineffective presentation of facts weakens the criticism and casts doubt on the precision of bank's assessment practice, exceptions in politics and administrative decreases related to credit problems.

Todorović Tomislav (2009): "Managing credit risk in banking”, Economic Horizons, 2/2009, 81-99

Smith Nigel J., Tony Merna, and Paul Jobling (2009): Managing risk: in construction projects, John Wiley \& Sons, 56

Vol. 12, No 3, 2015: 141-152 
Picture 1: Procedures for credit risk assessment with the phases of the process

Financial

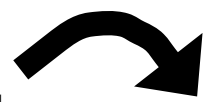

information

Analyses

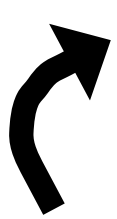

Credit description
Credit risk assessment

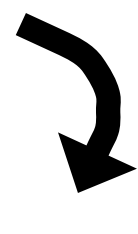

Conclusion

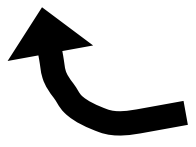

Title

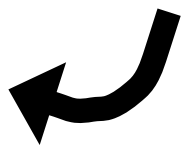

Source: The authors according to OCC 97-24, Models for taking out a loan, 2007.

Picture 1 shows the application of credit risk management procedure, which generally consists of five following parts: the title, credit description, financial information, analyses and in the end, conclusion. If a credit that is exposed to a classification or a specific purpose where a particular note refers to historically strong performance and realization of recent problems decreases temporary operation costs and as a result, there is a strong impact and working capital. This assessment also confirms a weak basis for controlling a loan.

\section{Regulatory framework for credit risk management}

The impact of economic crisis on the standards of Basel Committee on Banking Supervision has led to the changes and proposals for improvement of Basel II, resulting in creation of Basel III standards, intended primarily for strengthening the framework and providing the answers for the world economic crisis that unfortunately hit the banking world and other financial institutions worldwide. ${ }^{6}$ In order to enable that the regulatory framework complies continually with the standards of Basel Committee on Banking

$6 \quad$ LjubićMarijana, (2009): “Uticaj svetske ekonomskekrize na BazelII”, Časopis Računovodstvo, 11-12/2009, 94-108 
Supervision ${ }^{7}$ and EU regulations, Executive Board of the National Bank of Serbia adopted the Strategy for Introducing Basel III standards in Serbia in 2013. The focus was primarily on legal acts of the European Union for introduction of Basel III standards and compared to Basel documents, contain technical details.

The subjects of the analysis in the Strategy were the areas covered by Basel III (including Basel II and Basel 2.5) standards, as follows:

- Definition and elements of capital, indicators of capital adequacy;

- Capital requirements for credit risk - standardized approach;

- Capital requirements for credit risk - internal rating based approach (IRB approach);

- Capital requirements for credit risk - techniques for minimizing credit risk;

- Capital requirements for credit risk - securitization;

- Capital requirements for operational risk;

- Capital requirements for market risks;

- Great exposures;

- Liquidity coverage ratio indicator (LCR indicator);

- Capital buffers;

- Other (settlement/delivery risk, counterparty risk, credit valuation adjustment, data and information disclosure).

The focus was also on the acts of domestic regulations which were compared to the international standards and regulations, including the following:

- Banking law;

- Decision on capital adequacy;

- Decision on risk management in banks;

Recent Basel III standards are tighter and their adoption is expected to lead to a higher quality of capital basis of banks, more adequate risk management, introduction of a new parameter which would present the ratio between capital and total bank exposure (leverage ratio) and determination of its minimum level, introduction of measures that will require banks to set aside more assets that could be used in crises periods and introduction of two global liquidity standards for internationally active banks.

The adopted documents in the world stipulate the transition period for gradual introduction of new rules in the field of banking on the national level and the complete implementation of those rules is expected to take place on January $1^{\text {st }}, 2019$. Although Basel standards are not binding, their

The principal aim of BCBS is the improvement of understanding of key supervisory challenges and quality of bank supervision worldwide. Source: Bank for International Settlements (2006): International Convergence of Capital Measurement and Capital Standards, A Revised Framework, Comprehensive Version, June, 2006, 137

8 National Bank of Serbia (2013): Strategy for introduction of Basel III standards in Serbia, Belgrade 
adoption is expected to have a significant impact on the change of regulatory environment on banks and their operations. Since the introduction of Basel II was implemented in the time when Basel Committee on Banking Supervision had already announced Basel III, some of its elements were introduced in regulatory framework of the Republic of Serbia within the Decision on bank capital adequacy. That way, supplementary capital II (Tier 3) was excluded from the definition of regulatory capital, which contributed to strengthening capital quality, which now includes only fixed (Tier 1) and supplementary capital (Tier 2); another type of additional capital reserves for limiting distribution of profits(capital conservation buffer), has also been proscribed, where banks whose adequacy indicator was higher or would, due to the capital distribution, be higher than proscribed (12\%) by less than 2.5 percentage points can perform capital distribution only into the elements of fixed capital. The changed regulations, with the aim of compliance with the requirements of Basel III resulted in a different procedure for risk assessment. It would be logical to expect that tighter regulations for credit risk assessment result in higher quality placements and decreased credit activity of commercial banks. With the aim to gain an insight into changes caused by altered regulations, The National Bank of Serbia has, since 2014, been carrying out a survey on banks' credit activity in four time series. The survey includes all the aspects of credit market, and is methodologically in accordance with the survey conducted by central banks of the euro zone, with certain modifications. An alternative measure for statistical analysis of the survey results is diffusion index, which shows the net percentage that clearly differentiates between intensity of responses. Since a respondent gives the answer by choosing one of five options, it can be concluded that the answers to all five options are converted into numbers and thus are given numeric values ranging from -1 to 1 . The survey included 28 banks, out of the total number of 29 in $2014 .{ }^{9}$ The answers of different banks are related with their participation in the relevant credit market (the market that was included by the survey and the market of each individual bank)- the bigger the bank market share, the more importance should be given to its answer. Basel standards define market risk as a risk of losses in balance sheet and off balance sheet related positions deriving from changes in market prices ${ }^{10}$. A bank can be exposed to the market risk in the following positions ${ }^{11}$ :

1) bonds with fixed and flexible interest rates,

2) shares,

$9 \quad$ National Bank of Serbia (2014) List of banks, Belgrade http://www.nbs.rs/export/sites/ default/internet/latinica/50/50 2.html. (10.04.2015)

10 Christopher Ian Marrison, (2002): The Fundamentals of Risk Measurement, McGrawHill Professional, p. 42.

11 Vunjak Nened, Đurašinović Jelena, (2007): Determinants of risk in commercial banks, Seminar SM 2007, Risk management in strategic management, Proceedings on CD, Faculty of Economics, Subotica, p. 10. 
3) derivates based on different assets - shares, bonds, futures, etc.

4) credit transactions related with exchange rates and

5) credits with a foreign currency clause.

Borrower's credit rating is certainly the key to approving credit placements. Monitoring bank credit activities is a basis of adequate supervision and clear monitoring. The results of supervision that provided the data from surveyed banks clearly speak about the implementation of Basel standards in Serbia. The focus was only on the data related to credit activity of banks on the placements in foreign currency clause as follows: both short-term and long-term and credits for small, medium and big companies. With respect to compliance of rules and regulations in banks, Graphs 1 and 2 shows the impacts of factors on credit standards which banks apply in the process of loan approval or credit lines to companies in the last three months Graph 1 compared to previous three months Graph 2, and a prediction in the following three months compared to the last three months in 2014.

Graph 1: Foreign currency loans in the last three months

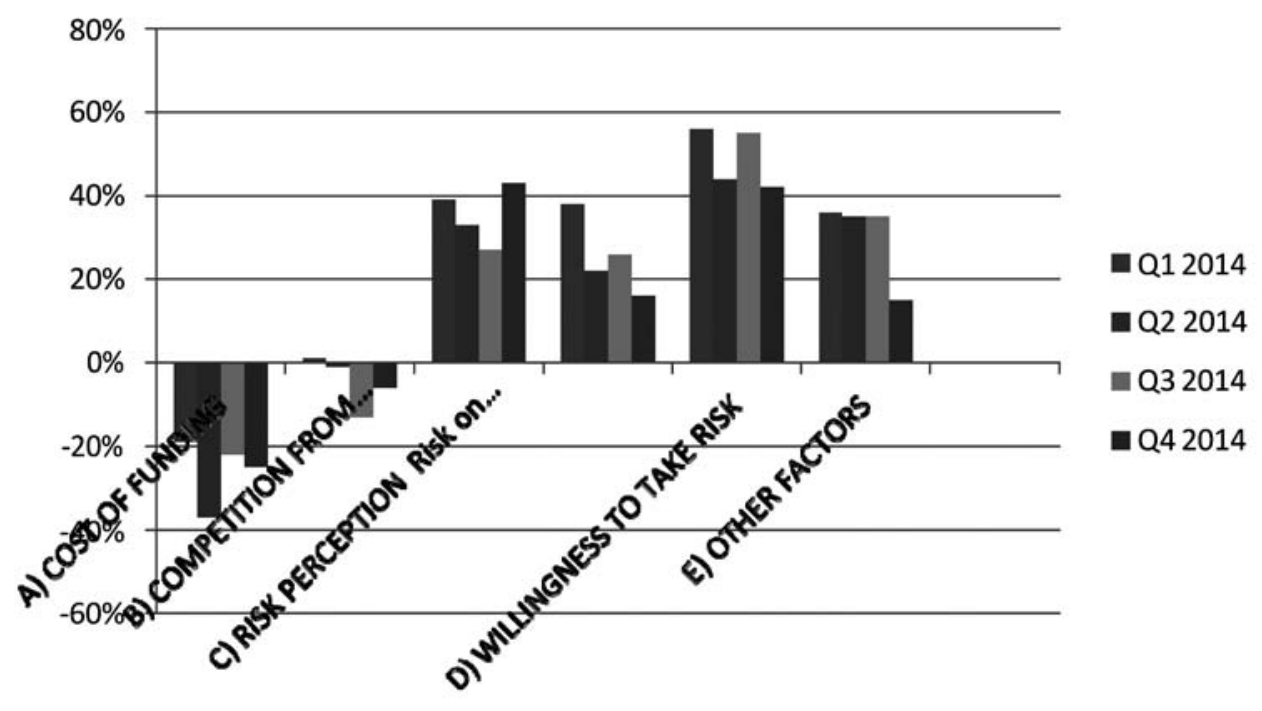

Source: The authors, based on Survey on banks' credit activities, Supervision Department, 2014 
Graph 2: Foreign currency loans in the following three months

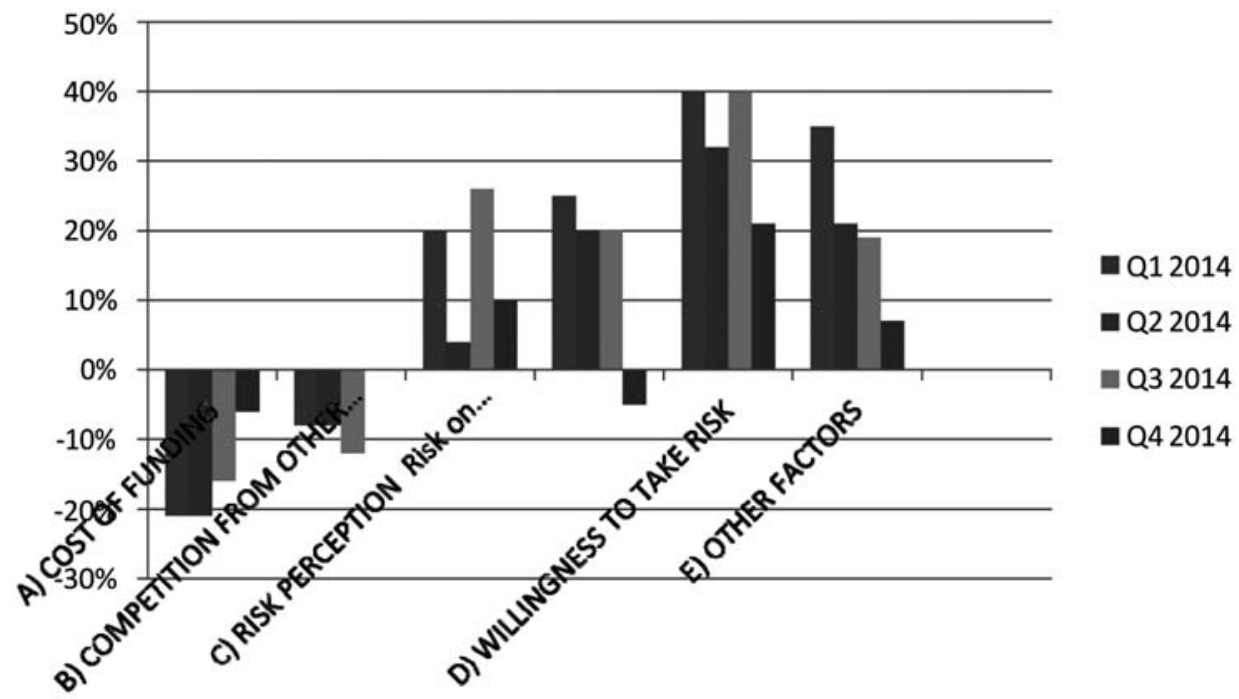

Source: The authors, based on Survey on banks' credit activities, Supervision Department, 2014

Graphs 3 and 4 show the data on the changes of company demand for loans and credit lines in the last three months Graph 3 in comparison with previous three months Graph 4 as a prediction for the following three months compared to last three months in 2014.

Graph 3: Company demand for loans and credit lines in the last three months

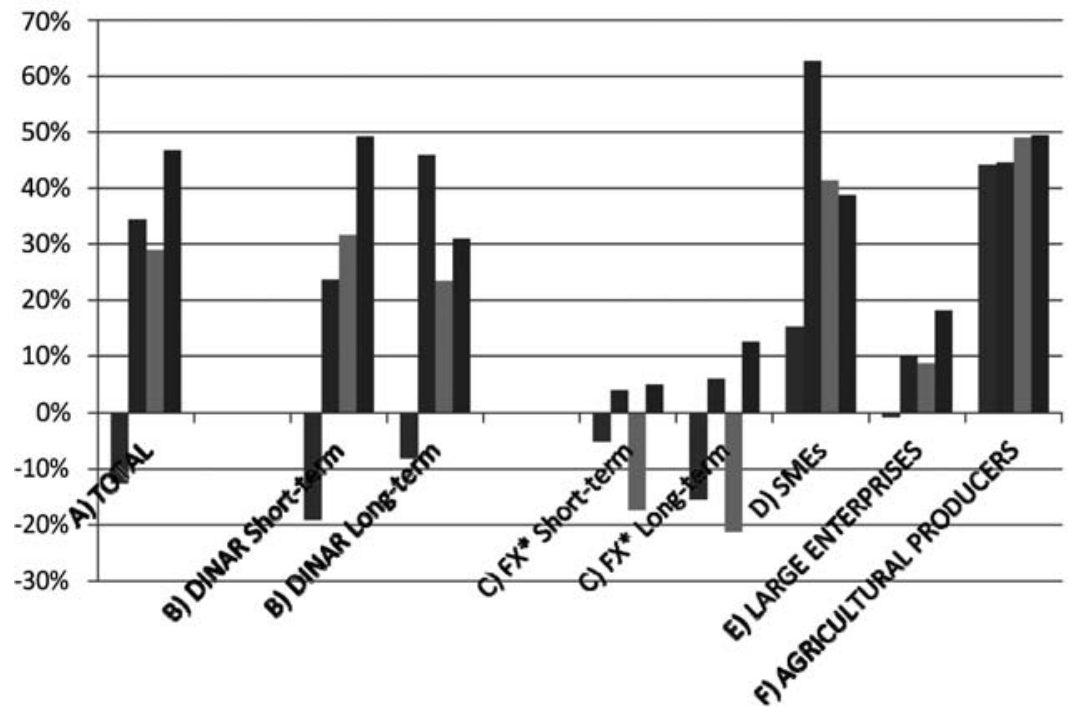

Q12014

- Q2 2014

- Q3 2014

- Q4 2014

Source: The authors, based on Survey on banks' credit activities, Supervision Department, 2014 
The impact of credit risk assessment on credit activity of commercial banks 149

Graph 4: Company demand for loans and credit lines in the following three months

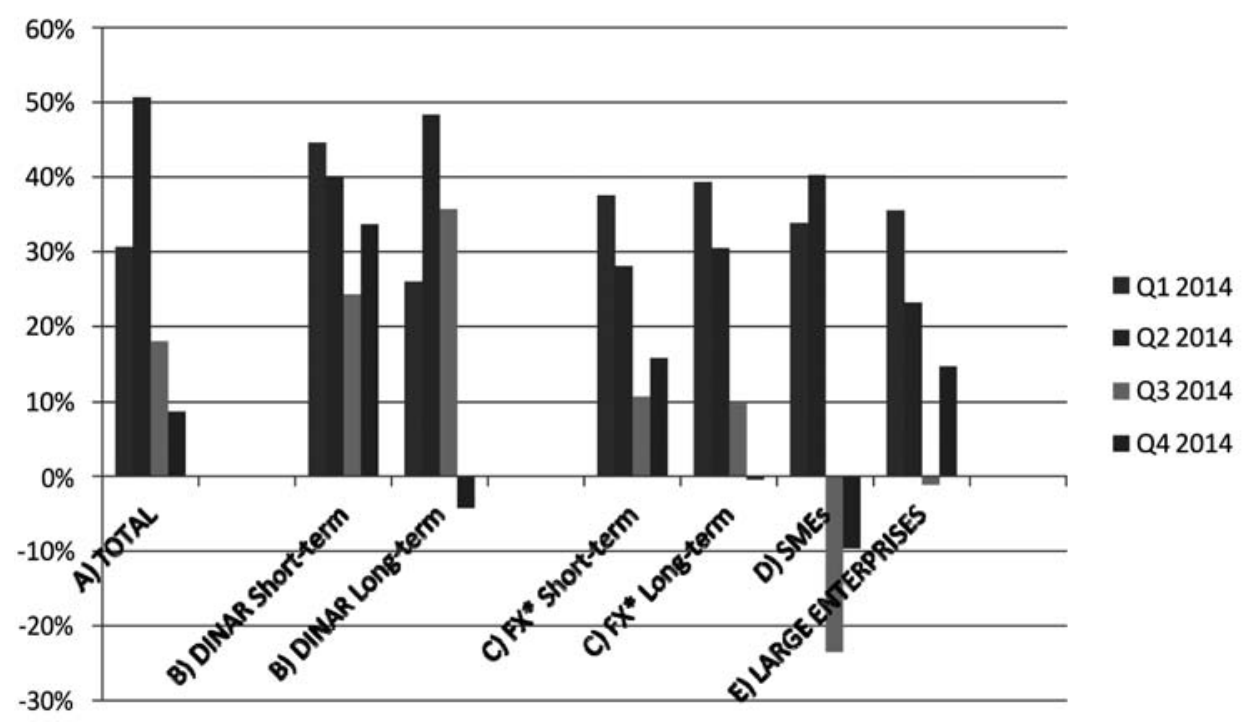

Source: The authors, based on Survey on banks' credit activities, Supervision Department, 2014

The above mentioned data show that credit activity of the banking sector in Serbia is on a high level, which is seen from Graphs 1 and 2, where the perception of risk of incollectability of accounts receivable in the previous three months (T1 56\%, T2 44\%, T3 55\%, T4 42\%) compared to the planned three months (T1 40\%, T2 32\%, T3 40\%, T4 21\%) is significantly lower, which contributes to stability of banking sector in Serbia. With respect to procedures and instructions used for managing credit risk in the most efficient way and the process of credit rating assessment of a borrower, the readiness of banks to take a risk is lower during the previous three months (T1 36\%, T2 35\%, T3 35\%, T4 15\%), compared to the planned three months (T1 35\%, T2 21\%, T3 19\%, T4 7\%), which contributes to a better understanding of the set standards and making business decisions.

Graphs 3 and 4 show that during last three months demand of companies for loans and credit lines increased. The total demand of companies for loans and credit lines in the last three months (T1-13\%, T2 34\%, T3 29\%,T4 47\%), compared to the following three months (T1 31\%, T2 51\%, T3 18\%, T4 9\%), increased in $\mathrm{T} 1$ and $\mathrm{T} 2$, while it decreased in $\mathrm{T} 3$ and $\mathrm{T} 4$. 


\section{Conclusion}

Regardless of the impact of the economic crisis, the banking system in Serbia has remained stable. The adequacy of banks' capital is higher than the proscribed $8 \%$ (Basel II), and above proscribed 12\% (Decision on capital adequacy) in accordance with Serbian regulations. Average adequacy of bank capital in Serbia remained at 16\% in 2014, which is more compared to the world standards. It is expected that capital adequacy will remain at the same level, having in mind that the banking sector in Serbia is stable, and banks are well capitalized.

Based on the share in the total balance sheet assets of the banking sector, $75 \%$ of banks are foreign, and their branches already implement Basel III capital standards, which makes the application process easier in Serbia.

Compliance of regulations with world standards in banking operations contributes to efficiency of credit policies to a great extent, which easies the process of making business decisions. The aim of it is the application of the elements of standards for improvement of internal processes of credit risk rating.

On the other hand, a tighter method of assessment of exposure to credit risk results in decrease of credit activity of banks. As Serbian financial system is extremely bank centered and Serbian economy is facing major problems, a tighter assessment of credit risk will put a substantial number of companies in a difficult position when it comes to the possibility of funding the development and the need for working capital.

\section{Literature}

- Bank for International Settlement (2006): International Convergence of Capital Measurement and Capital Standards, A Revised Framework, Comprehensive Version, Basel, June, 2006

- Basel Committee on Banking Supervision (2009): Principles for Sound Stress Testing Practices and Supervision, Basel, 13-23

- Jaime Caruana, General Manager of the BIS (2010): "Basel III: towards a safer financial system", Speach delivered at The 3rd Santander International Banking Conference, Madrid, September $15^{\text {th }}, 2010$

- Basel Committee on Banking Supervision (2008): Principles for Sound Liquidity Risk Management and Supervision, Basel

- Basel Committee on Banking Supervision (2006): Basel II, International Convergence of Capital Measurement and Capital Standards: A Revised Framework - Comprehensive Version, June 2006 
- Christopher Ian Marrison, (2002): The Fundamentals of Risk Measurement, McGraw- Hill Professional

- Comptroller's Handbook, (2001): Rating Credit Risk, Comptroller of the Currency Administrator of National Banks, Washington D,C,

- Simon Turmaine (2013) "Basel III global monitor", Global Risk Regulator, $1 / 2013$, p. 8

- Simon Turmaine (2009) "Basel II impact study: Bank capital too low to absorb market risk", Global Risk Regulator, 1/2009, p. 13

- Ljubić Marijana (2011): "Stress tests as an instrument of risk control in banks", Megatrend Review, 1/2011, 303-324

- Ljubić Marijana (2009): “Uticaj svetske ekonomske krize na Bazel II, Accounting, 11-12/2009, 94-108

- National Bank of Serbia (2013): Strategy for introduction of Basel III standards in Serbia, Belgrade

- National Bank of Serbia (2014), List of banks, Belgrade

- $\quad$ http://www.nbs.rs/export/sites/default/internet/latinica/50/50_2.html. (10.04.2015)

- National Bank of Serbia, (2015), Report on the results of the bank lending survey 2014, Supervision Department, Belgrade.

- Todorović Tomislav (2009): "Managing credit risk in banking", Economic Horizons, 2/2009, 81-99

- Smith, Nigel J., Tony Merna, and Paul Jobling (2009): Managing risk: in construction projects, John Wiley \& Sons

- Vunjak Nenad, Đurašinović Jelena, (2007): "Determinants of risk in commercial banks", Seminar SM 2007, Risk management in strategic management, Proceedings on CD, Faculty of Economics, Subotica 
Dr Marijana Ljubić, vanredni profesor

Fakultet za poslovne studije,

Univerzitet „Džon Nezbit“ (Megatrend univerzitet), Beograd

Prof. dr Vladan Pavlović

Ekonomski fakultet, Kosovska Mitrovica, Univerzitet u Prištini

Prof. dr Srećko Milačić

Ekonomski fakultet, Kosovska Mitrovica, Univerzitet u Prištini

\section{UTICAJ OCENE KREDITNOG RIZIKA NA KREDITNU AKTIVNOST POSLOVNIH BANAKA}

\section{S a ž e $t$ a k}

S obzirom na to da banke imaju veliku društvenu odgovornost i da upravo zato njihovo poslovanje i jeste predmet posebne i obimnije regulacije, a da je Bazel jedna od njih, autori u radu stavljaju akcenat na veliki uticaj načina ocenjivanja kreditnog rizika na aktivnost banaka, a samim tim i na donošenje poslovnih odluka. U radu autori daju standard za upravljanje rizikom, osvrt na uputstva, kako da se na najefikasniji način upravlja kreditnim rizikom i na koji način se procenjuje kreditni bonitet zajmoprimca.

Ključne reči: Bazel II i III, kreditni rizik, kreditna aktivnost banaka, kreditni bonitet zajmoprimca, upravljanje rizikom. 